\title{
Biochemical and haematological safety evaluation of the ethanol extract of the stem bark of Blighia sapida using Swiss albino mice
}

\section{Chinweizu Ejikeme Udobi ${ }^{*}$, Betseabasi Edward Umoh ${ }^{2}$ and Ememobong Gideon Asuquo ${ }^{1}$}

\author{
${ }^{1}$ Pharmaceutical Microbiology Unit, Department of Pharmaceutics and Pharmaceutical Technology, Faculty of \\ Pharmacy, University of Uyo, Nigeria. \\ ${ }^{2}$ Centre for Wetlands and Waste Management Studies, Faculty of Agriculture, University of Uyo, Nigeria.
}

${ }^{*}$ Corresponding author. Email: ceudobi@yahoo.com

\begin{abstract}
Copyright @ 2017 Udobi et al. This article remains permanently open access under the terms of the Creative Commons Attribution License 4.0, which permits unrestricted use, distribution, and reproduction in any medium, provided the original work is properly cited.
\end{abstract}

Received 16th February, 2017; Accepted 28th March, 2017

\begin{abstract}
The ethanol extract of the stem bark of Blighia sapida was studied for its toxic effects on certain hematological and biochemical indices of the swiss albino mice. Three different concentrations of the extract were administered to different groups of the mice through their drinking water for 14 days in the sub-acute test and 28 days in the case of the chronic test. Preliminary phytochemical screening showed that the plant contains bioactive compounds such as saponins, polyphenols, flavonoids, terpenes, resins, alkaloids, carbohydrates, cardiac glycosides, and tannins. The LD 50 of the extract was determined to be $500 \mathrm{mg} / \mathrm{kg}$ body weight using the Lorke method. Other results obtained showed a significant decrease in some haematological indices such as PCV, HB, RBC, MCV, WBC, lymphocytes and platelet levels as the doses administered increased from low to high. There was also, a significant decrease in the levels of certain biochemical indices such as total protein, albumin, globulin, urea and AST, while the levels of ALT and ALP were significantly increased. The ethanol extract of the stem bark of Blighia sapida showed a slight toxicity to the swiss albino mice. It also showed ability to precipitate some level of anaemia and hepatic damage. Result obtained also confirms that the extract has anticoagulant properties. The safety implications of these effects are highlighted.
\end{abstract}

Key words: Ethanol extract, stem bark, swiss albino mice, biochemical, haematological.

\section{INTRODUCTION}

Medicinal plants play a vital role in the management of various diseases (Olatunji and Atolani, 2009). Scientific investigations of medicinal plants have been initiated in many countries because of their contributions to health care. The continual search for and the interest in natural plant products for use as medicines has continued to act as the catalyst for exploring methodologies involved in obtaining the required plant materials and probing their constituents for safety for human use (Okoli, 2004).

The amount of pharmacological substances and chemicals being used in the human community today has increased tremendously. These are today in the form of or as constituents of food substances, medicines, and beverages, other industrial and household products.
However, pharmacological substances may result in chronic toxicity in the living system when used over a long period of time or acute toxicity may result when large quantities capable of eliciting immediate toxic effect are used. These effects may be mild or severe, depending on the nature of the substance.

Preparations from plants known to have medicinal values have been used in Africa by the locals mostly in their crude form for a very long time. In most of these places, these preparations are the only medications known to serve the populace. They meet the medicinal needs of the people by curing a wide range of diseases. This is because plants are known to have the ability to produce and store a wide range of chemical substances. 
Some of these substances have the ability to defend the plants against microbial attack while others confer some other abilities on the plants. The importance of these plants is however undermined by the fact that most of them exhibit different levels of toxicity (Veeramuthu et al., 2006).

Toxicity study is therefore necessary before these plants can be used as medications by humans. Toxicity study is the determination of potential hazards a test substance may likely produce and the characterization of its action. Most of the toxicity testing is carried out on experimental animals (Craig, 1999). The advantages of using animal models in toxicity testing are enormous. They include the possibility of clearly defined genetic constitution and their amenity to controlled exposure, controlled duration of exposure, and the possibility of detailed examination of all tissues (Arome, 2013).

Blighia sapida belongs to the family Sapindaceae. In Nigeria, it is known as akee and ishin. It has many other local names in other western Africa countries (Micheal et al., 1998). The tree is usually densely branched and symmetrical with smooth gray bark. It is about $40 \mathrm{ft}(12 \mathrm{~m})$ tall and possesses evergreen (rarely deciduous) alternate leaves.

All parts of the plant have been used in traditional practice for the treatment of several ailments. For example, the aqueous extract of the seeds of Blighia sapida administered as parasite expellant. The crush new foliage is applied on the forehead as headache relief and the juice from the leaf is applied as eye drops in cases of conjunctivitis. Various preparation and combinations of the extracts have also been made for the treatment of diseases such as dysentery, epilepsy, yellow fever (Kubmarawa et al., 2007) and diabetics (Kokwaro, 2000). The crushed seeds have been used to treat dental decay while the crushed bark are used for wound healing and decoction of the bark is used for constipation (Ekue et al., 2010). The plant has also been reported to be effective against cold and pain when applied; it is also acaricidal and insecticidal (Ashurust, 2001).

The inedible portion of the plant contains the toxins hypoglycin A and hypoglycinB (Blanke et al., 2006). Hypoglycin $A$ is found in both seeds and arils, while hypoglycin $B$ is found only in the seeds. Hypoglycin is converted in the body to methylene cyclopropyl acetic acid (MCPA). Hypoglycin and MCPA are both toxic. MCPA inhibits several enzymes involved in the breakdown of acyl CoA compounds. Hypoglycin combines irreversibly with Coenzymes $A$, carnitine and carnitine acyltransferases I and II reducing their bioavailability and consequently inhibiting beta oxidation of fatty acids. Beta oxidation normally provides the body with ATP, NADH and acetyl CoA which is used to supplement the energy produced by glycolysis. Glucose stored are consequently depleted leading to hypoglycemia (Olatunji and Atolani, 2009). Blighia sapida has been used extensively in the West African region for medicinal purposes neglecting the toxicity aspect of the plant. Results obtained from this study will therefore guide in confirming their safety and hence usage in traditional medical practice.

\section{MATERIALS AND METHODS}

\section{Plant collection and authentication}

The stem bark of B.Sapida was collected from Itak Ikot Akap, Ikono Local Government Area, Akwa Ibom State, Nigeria. The authentication of the plants was done by Prof. Margaret Bassey of the Department of Botany and Ecological studies, Faculty of Science, University of Uyo and a voucher specimen with herbarium No. 69(a) was deposited in the herbarium of the Faculty of Pharmacy, University of Uyo, Nigeria.

\section{Preparation and extraction of plant material}

The stem bark of B.sapida was properly washed, chopped into pieces and air dried for two weeks. They were ground into powder and extracted using $75 \%$ ethanol. The extract was obtained by soaking $300 \mathrm{~g}$ of the dried powdery samples in $2500 \mathrm{ml}$ of ethanol for 48 hrs during which the mixture was intermittently shaken. It was later filtered through Whatman filter paper. The extracts were evaporated to dryness at $40^{\circ} \mathrm{C}$ in a water bath. This temperature was maintained to avoid the chemical components from being destroyed.

\section{Animal treatment}

The animals used for this study were Swiss albino mice. They were maintained at the Experimental Animal House of the Department of Pharmacology and Toxicology, Faculty of Pharmacy, University of Uyo, Nigeria. They were kept in rat cages and fed with standard pellet feeds and allowed free access to clean fresh water. All experimental protocols were in compliance with the Faculty of Pharmacy, University of Uyo Ethics on Research in Animals as well as internationally accepted principles for laboratory animal use and care.

\section{Phytochemical screening}

Phytochemical screening was done to determine the chemical constituents of the plant extract. These include test for alkaloids, Cardiac Glycosides, Cyanogenic Glycosides, flavonoids, resins, Polyphenols (Trease and Evans 2009), saponins, phlobatanins, Anthraquinones, carbohydrates Balsams, (Sofowora, 2008) Terpenes, tannins (Harborne, 1973). 


\section{Toxicity studies}

\section{Acute toxicity test}

Determination of Lethal dose $\left(\operatorname{LD}_{50}\right)$ : The Lorke method was used to determine the concentration of the extracts of the stem bark of Blighia sapida that killed $50 \%$ of the test animal population (Lorke, 1983). The animals used for this study were Swiss albino mice (weighing between 22 and $34 \mathrm{~g}$ ). They were divided into groups, with three animals per group. The test was in two phases. In the first phase, each group of the animals was administered with $3000 \mathrm{mg} / \mathrm{kg}, 2000 \mathrm{mg} / \mathrm{kg}$ and $1500 \mathrm{mg} / \mathrm{kg}$ of the extract. The animals were monitored for $24 \mathrm{hrs}$ and mortalities noted. In the second phase, each group was administered with $250 \mathrm{mg} / \mathrm{kg}, 500 \mathrm{mg} / \mathrm{kg}$ and $1000 \mathrm{mg} / \mathrm{kg}$ of the extract. They were monitored for $24 \mathrm{hrs}$ and mortalities noted. All extract administrations were done through the intraperitoneal route. The Lethal Dose $\left(L_{50}\right)$ was determined using Highest dose that gave no mortality $\left(D_{0}\right)$ and Lowest dose that produced mortality (D100) (Lorke, 2003).

\section{Sub-acute toxicity test}

After 14 days of administration of the extracts of the stem bark of Blighia sapida, the mice were randomly selected irrespective of sex and weight and divided into four groups which were the Low Dose (LD), Middle Dose (MD), High Dose (HD) and the Control groups. The LD50 was used as baseline dose (i.e. low dose) while the middle and the high doses were obtained by doubling and tripling the $\mathrm{LD}_{50}$ respectively according to the method of the American Association of Clinical Chemistry, (2014). The animals were fed with standard pellets feeds and clean water. The test groups had their extracts added to their drinking water to avoid injection abscess which may kill the animal if given by injection (Pincus et al., 2011), while the control group was fed with standard pellets feed but given only potable drinking water. Doses of the extract administered were $500 \mathrm{mg} / \mathrm{kg}, 1000 \mathrm{mg} / \mathrm{kg}$ and $1500 \mathrm{mg} / \mathrm{kg}$. The doses were administered daily through the same route for 14 days. Observation was done every 24 hours. After the test period, the animals were suffocated using chloroform and sacrificed. Sterile syringes with needles were used to collect the blood from the heart of the sacrificed animal by process known as Cardiac Puncture (American Association of Clinical Chemistry, 2014). The blood samples were analyzed for the effect of the extracts on some hematological and biochemical indices using the Mindray 5 part Differential Haematological Auto-analyzer (BC-5300)

Hematological safety evaluation: Using the blood sample obtained, laboratory analysis was carried out to determine the effect of the extracts on certain hematological parameters in the blood. They include Pack Cell Volume (PCV), Hemoglobin (HB), Mean
Corpuscular Hemoglobin Concentration (MCHC), Mean Corpuscular Values (MCV), Mean Corpuscular Hemoglobin (MCH), Red Blood Cell (RBC), White Blood cell (WBC), Lymphocytes, Neutrophils, Monocytes, Eosinophil, and Platelets. The sample specimen bottle was properly labelled, imputed into the computer attached to the auto analyzer and saved accordingly. 3 to $5 \mathrm{ml}$ of blood in a specimen bottle was mixed thoroughly to avoid clusters or larger particles from blocking the tiny tubing in the auto analyzer as this will damage the machine. The auto analyzer was turned on and allowed to self-calibrate (self-check). When it was ready, a beeping noise was heard as prompt sound. The analyzer brought down a prop (a tube-like part of the machine) and sucked the blood sample from the specimen bottle after which the cycle of analysis began. The analyzer automatically separated every parameter and sent the result to the monitor which was later printed.

Biochemical safety evaluation: Laboratory analysis was also carried out to determine the effect of the extract on certain biochemical parameters in the system which includes total protein, albumin, urea, globulin, Aspartate aminotransferase (AST), Alkaline Phosphatase (ALP) and Alanine Aminotransferase (ALT). The method was as in heamatological parameters. The analyzer automatically separated the hematological parameters and biochemical parameters and displayed all the result on the monitor.

Chronic toxicity: This was determined after 28 days of administration of the extracts of the stem bark of $B$. sapida. The mice were randomly selected and divided into four groups; the Low Dose, Middle Dose, High Dose and the Control groups. The test mice were fed with standard pellets feed and the extract added to their drinking water while the control was fed with the standard pellets feed and potable drinking water only. The extracts were added to their drinking water to avoid injection abscess which may kill the animal if given by injection (Pincus et al., 2011). The test animals were also divided into three groups with three animals in each group. Three different doses of the extract namely, high dose (HD), middle dose (MD) and low dose (LD) were administered to each group. The $\mathrm{LD}_{50}$ was used as baseline dose (i.e. low dose) while the middle dose and the high dose were obtained by doubling and tripling the $\mathrm{LD}_{50}$ according to the method of the American Association of Clinical Chemistry, (2014). Dose of $B$. sapida extract administered were $500 \mathrm{mg} / \mathrm{kg}$ for Low dose (LD), 1000 $\mathrm{mg} / \mathrm{kg}$ for Middle dose (MD) and $1500 \mathrm{mg} / \mathrm{kg}$ for High dose (HD). After 28 days, the animals were suffocated using chloroform and sacrificed. Sterile syringe with needle was used to collect the blood from the heart of the sacrificed animal by process known as Cardiac Puncture (Pincus et al., 2014). The blood sample was collected and stored in a heparinized specimen bottle with anti- 
Table 1. Results of the phytochemical screening of the ethanol extract of the stem bark of Blighia sapida.

\begin{tabular}{lc}
\hline Constituents & Indications \\
\hline Saponins & + \\
Polyphenols & + \\
Flavonoids & + \\
Steroid glycosides & - \\
Terpenes & + \\
Phlobatanins & - \\
Aanthraquinone & - \\
Cyanogenic glycoside & - \\
Balsam & + \\
Resins & + \\
Alkaloids & + \\
Carbohydrates & + \\
Cardiac glycosides & + \\
Cardenolides & + \\
Tannins & + \\
\hline
\end{tabular}

Table 2. Result of the acute toxicity test for ethanol extract of the stem bark of Blighia sapida.

\begin{tabular}{|c|c|c|c|c|c|}
\hline Phases & Dose $(\mathrm{mg} / \mathrm{kg})$ & No. of mice & Mortality & $\%$ Mortality & LD50(mg/kg) \\
\hline \multirow[t]{3}{*}{1} & 3000 & 3 & 3 & 100 & \multirow{6}{*}{$\begin{array}{l}\sqrt{ } D_{0} X D_{100} \\
=500 \mathrm{mg} / \mathrm{kg}\end{array}$} \\
\hline & 2000 & 3 & 3 & 100 & \\
\hline & 1500 & 3 & 3 & 100 & \\
\hline \multirow[t]{3}{*}{2} & 1000 & 3 & 3 & 100 & \\
\hline & 500 & 3 & 2 & 66.67 & \\
\hline & 250 & 3 & 0 & 0 & \\
\hline
\end{tabular}

D0, hightest dose that gave no mortality, $250 \mathrm{mg} / \mathrm{kg}$ body weight; D100, lowest dose that produced mortality, $1000 \mathrm{mg} / \mathrm{kg}$.

coagulant and the specimen bottle with the blood sample was shaken briskly to prevent the blood from clotting. The blood samples were taken to the laboratory to be analyzed for the effect of the extracts on some hematological and biochemical indices

\section{Statistical analysis}

Statistical analysis was done using windows SPSS package (SPSS version 15.0). Data was analyzed using one way ANOVA followed by post hoc t-test least significance difference (LSD). The data were expressed as mean \pm standard error and values of $p<0.05$ were considered significant.

\section{RESULTS}

\section{Phytochemical screening}

The result of the phytochemical screening of the ethanol extract of the bark of B.sapida revealed the presence of saponins, tannins, terpenes, cardenolide, Balsam, alkaloid, carbohydrate, flavonoids and cardiac glycosides. However phlobatanins, cyanogenic glycoside, Steroid glycoside and anthraquinones were absent (Table 1).

\section{Acute toxicity}

Results of the acute toxicity test of the ethanol extract of the stem bark of B.sapida are presented in Table 2. On administration of the extract, physical signs like dullness, rubbing of nose and mouth on the floor of the cage along with restlessness were shown by the animals. When the $\mathrm{LD}_{50}$ was computed, it was found to be $500 \mathrm{mg} / \mathrm{kg}$.

\section{Sub-acute toxicity}

\section{Hematological safety evaluation}

The ethanol extract of the stem bark of $B$. sapida was 
Table 3a. Result showing the sub-acute effect of the administration of the ethanol extract of the stem bark of Blighia sapida on Red blood cell indices of Swiss albino rats.

\begin{tabular}{lcccccc}
\hline Groups & PCV $(\%)$ & HB $(\mathbf{g} / \mathbf{d L})$ & RBC $\left(\times 10^{6} / \mu L\right)$ & MCV $\left(\mu m^{3}\right)$ & MCH $(\mathbf{p g})$ & MCHC $(\mathbf{g} / \mathbf{d L})$ \\
\hline Low dose & $46.9 \pm 1.3^{* *}$ & $14.4 \pm 1.2^{* *}$ & $7.57 \pm 1.2^{* *}$ & $52.8 \pm 2.3^{* *}$ & $15.6 \pm 1.5$ & $28.8 \pm 2.9^{* *}$ \\
Middle dose & $46.1 \pm 5.6^{\star *}$ & $13.1 \pm 3.5^{*}$ & $7.29 \pm 1.9^{* *}$ & $51.7 \pm 3.4^{* *}$ & $15.1 \pm 2.5$ & $30.1 \pm 2.0$ \\
High dose & $42.8 \pm 2.7^{*}$ & $12.1 \pm 2.4^{\star *}$ & $6.90 \pm 1.5^{*}$ & $50.3 \pm 2.4$ & $13.8 \pm 3.0^{* *}$ & $30.7 \pm 1.3$ \\
Control & $48.2 \pm 1.3$ & $15.7 \pm 1.4$ & $9.32 \pm 1.1$ & $49.4 \pm 1.0$ & $15.8 \pm 0.9$ & $31.2 \pm 1.2$ \\
\hline
\end{tabular}

Values presented as mean \pm SEM, Significance relative to control: ${ }^{* *} \mathrm{p}<0.01,{ }^{*} \mathrm{p}<0.05$.

Table 3b. Result showing the sub-acute effect of the administration of the ethanol extract of the stem bark of Blighia sapida on Total WBC, differential and platelet count of Swiss albino rats.

\begin{tabular}{|c|c|c|c|c|c|c|}
\hline Groups & WBC $\left(\times 10^{3} / \mu \mathrm{L}\right)$ & LYM $\left(x 10^{3} / \mu \mathrm{L}\right)$ & NEU $\left(\times 10^{3} / \mu \mathrm{L}\right)$ & MON $\left(\times 10^{3} / \mu \mathrm{L}\right)$ & $\operatorname{EOS}\left(\times 10^{3} / \mu \mathrm{L}\right)$ & Platelet $\left(x 10^{3} / \mu \mathrm{L}\right)$ \\
\hline Low dose & $13.5 \pm 1.5^{\star}$ & $10.5 \pm 0.8^{*}$ & $2.1 \pm 0.3^{*}$ & $0.23 \pm 0.2$ & $0.03 \pm 0.1$ & $6255 \pm 17.6^{*}$ \\
\hline Middle dose & $11.3 \pm 4^{*}$ & $8.4 \pm 2.8^{*}$ & $1.5 \pm 0.6^{*}$ & $0.3 \pm 0.1$ & $0.0-0.0$ & $567 \pm 19.2^{*}$ \\
\hline High dose & $11.0 \pm 2.4^{*}$ & $7.8 \pm 2.1^{* *}$ & $1.2 \pm 0.9^{* *}$ & $0.7 \pm 0.2^{*}$ & $0.0-0.0$ & $555 \pm 30.3^{*}$ \\
\hline Control & $7.9 \pm 1.2$ & $6.3 \pm 0.8$ & $0.7 \pm 0.1$ & $0.4 \pm 0.1$ & $0.03 \pm 0.1$ & $538 \pm 22.1$ \\
\hline
\end{tabular}

Values presented as mean \pm SEM, Significance relative to control: ${ }^{* *} p<0.01,{ }^{*} p<0.05$.

Table 3c. The sub-acute effect of the ethanol extract of the stem bark of Blighia sapida on biochemical indices of Swiss albino rat.

\begin{tabular}{lccccccc}
\hline Groups & Total protein $(\mathbf{g} / \mathbf{L})$ & Albumin $(\mathbf{g} / \mathbf{L})$ & Globulin $(\mathbf{g} / \mathbf{L})$ & Urea $(\mathbf{m m o l} / \mathbf{L})$ & AST $(\mathbf{i u} / \mathbf{L})$ & ALT $(\mathbf{i u} / \mathbf{L})$ & ALP $(\mathbf{i u} / \mathbf{L})$ \\
\hline Low dose & $82.7 \pm 2.3^{*}$ & $39.3 \pm 1.5^{*}$ & $43.7 \pm 1.5^{*}$ & $6.4 \pm 0.1^{* *}$ & $105.3 \pm 2.1^{*}$ & $33.3 \pm 2.1$ & $243 \pm 17.8^{*}$ \\
Middle dose & $75.3 \pm 1.5^{*}$ & $35.3 \pm 1.5$ & $39.3 \pm 2.1^{* *}$ & $6.1 \pm 2.2^{* *}$ & $100.7 \pm 2.5^{*}$ & $41.3 \pm 1.2^{*}$ & $317 \pm 5.3^{*}$ \\
High dose & $64.3 \pm 1.5^{* *}$ & $35.3 \pm 3.2$ & $27.3 \pm 1.5^{*}$ & $4.7 \pm 0.5$ & $97.7 \pm 6.4^{* *}$ & $41.3 \pm 1.5^{*}$ & $319.3 \pm 9.5^{*}$ \\
Control & $71.3 \pm 0.6$ & $37 \pm 2.0$ & $35.7 \pm 1.2$ & $5.7 \pm 0.1$ & $94.7 \pm 1.5$ & $34.3 \pm 2.3$ & $335 \pm 1.0$ \\
\hline
\end{tabular}

$\mathrm{iu} / \mathrm{L}$ (international unit/litre), Values presented as mean \pm SEM, Significance relative to control: ${ }^{* *} \mathrm{p}<0.01,{ }^{*} \mathrm{p}<0.05$.

observed to cause decrease in the PCV, HB, RBC, MCV, WBC, lymphocytes, neutrophils and platelet levels as the doses administered increased from low dose to high dose while the MCHC level increased as shown in Table $3 a$ and $3 b$.

\section{Biochemical safety evaluation}

The ethanol extract of the stem bark of Blighia sapida was observed to cause decrease in total protein, albumin, globulin, urea and aspartate aminotransferase (AST) levels as the doses administered increased from low dose to high dose while alanine aminotransferase (ALT) and alkaline phosphatase (ALP) level increased (Table 4c).

\section{Chronic toxicity test}

\section{Hematological safety evaluation}

The ethanol extract of the stem bark of Blighia sapida was observed to cause decrease in the packed cell volume, hemoglobin, red blood cell, mean corpuscular volume, white blood cell, lymphocytes, neutrophils and platelet levels as the doses administered increased from low dose to high dose while the mean corpuscular hemoglobin concentration level increased (Table 4a and $4 b)$.

\section{Biochemical safety evaluation}

The ethanol extract of the stem bark of Blighia sapida was observed to cause decrease in total protein, albumin, globulin, urea and aspartate aminotransferase (AST) levels as the doses administered increased from low dose to high dose while alanine aminotransferase (ALT) and alkaline phosphatase (ALP) level increased.

\section{DISCUSSION}

In developing countries, herbal products from medicinal plants found everywhere within the environment have become famous in healthcare and some have been falsely considered as safe because they are obtained from natural sources. Bioactive compounds from 
Table 4a. Result showing the chronic effect of the administration of the ethanol extract of the stem bark of Blighiasapida on Red blood cell indices of Swiss albino rats.

\begin{tabular}{lcccccc}
\hline Groups & PCV $(\%)$ & HB $(\mathbf{g} / \mathbf{d L})$ & RBC $\left(\times 10^{6} / \mu L\right)$ & MCV $(\mu \mathrm{m} 3)$ & MCH $(\mathbf{p g})$ & MCHC $(\mathbf{g} / \mathbf{d L})$ \\
\hline Low dose & $43.3 \pm 0.6^{* *}$ & $11.1 \pm 1.3^{*}$ & $4.6 \pm 2.1^{*}$ & $49.4 \pm 2.2$ & $12.5 \pm 1.2^{* *}$ & $32.8 \pm 2.9^{* *}$ \\
Middle dose & $38.3 \pm 1.5^{*}$ & $10.2 \pm 2.6^{*}$ & $3.97 \pm 1.1^{*}$ & $47.5 \pm 1.7^{* *}$ & $10.8 \pm 2.2^{* *}$ & $34.1 \pm 4.3^{* *}$ \\
High dose & $36.3 \pm 3.2^{*}$ & $8.7 \pm 1.7^{*}$ & $3.3 \pm 1.0^{*}$ & $45.9 \pm 2.0^{* *}$ & $9.6 \pm 2.2^{*}$ & $36.6 \pm 5.3^{*}$ \\
Control & $48.2 \pm 1.3$ & $15.7 \pm 1.4$ & $9.32 \pm 1.1$ & $49.4 \pm 1.0$ & $15.8 \pm 0.9$ & $31.2 \pm 1.2$ \\
\hline
\end{tabular}

Values presented as mean \pm SEM, Significance relative to control: ${ }^{* *} \mathrm{p}<0.01,{ }^{*} \mathrm{p}<0.05$.

Table 4b. Result showing the chronic effect of the administration of the ethanol extract of the stem bark of Blighia sapida on Total WBC, differential and platelet count of Swiss albino mice.

\begin{tabular}{|c|c|c|c|c|c|c|}
\hline Groups & WBC $\left(\times 10^{3} / \mu / L\right)$ & $\operatorname{LYM}\left(\times 10^{3} / \mu / L\right)$ & $\operatorname{NEU}\left(\times 10^{3} / \mu / L\right)$ & $\operatorname{MON}\left(\times 10^{3} / \mu / L\right)$ & $\operatorname{EOS}\left(\times 10^{3} / \mu / L\right)$ & Platelet $\left(\times 10^{3} / \mu / L\right)$ \\
\hline Low dose & $10.8 \pm 0.95^{\star}$ & $8.5 \pm 0.7^{*}$ & $1.1 \pm 0.2^{*}$ & $0.3 \pm 0.3$ & $0.0-0.0$ & $642 \pm 12.5^{*}$ \\
\hline Middle dose & $8.1 \pm 3.0^{*}$ & $5.3 \pm 0.9$ & $0.8 \pm 0.4$ & $0.5 \pm 0.1$ & $0.0-0.0$ & $559 \pm 22.0^{*}$ \\
\hline High dose & $6.8 \pm 2.2^{\star *}$ & $5.1 \pm 0.9$ & $0.5 \pm 0.4$ & $0.8 \pm 0.2$ & $0.0-0.0$ & $548 \pm 25.8^{*}$ \\
\hline Control & $7.9 \pm 1.2$ & $6.3 \pm 0.8$ & $0.7 \pm 0.1$ & $0.4 \pm 0.1$ & $0.03 \pm 0.1$ & $538 \pm 22.1$ \\
\hline
\end{tabular}

Values presented as mean \pm SEM, Significance relative to control: ${ }^{* *} p<0.01,{ }^{*} p<0.05$.

Table 4c. Result showing the chronic effect of the ethanol extract of the stem bark of Blighia sapida on biochemical indices of Swiss albino rat.

\begin{tabular}{|c|c|c|c|c|c|c|c|}
\hline Groups & Total protein $(\mathrm{g} / \mathrm{L})$ & Albumin (g/L) & Globulin (g/L) & Urea (mmol/L) & AST (iu/L) & ALT (iu/L) & ALP (iu/L) \\
\hline Low dose & $78.7 \pm 2.5^{\star}$ & $37.6 \pm 2.5$ & $39 \pm 1.7^{* *}$ & $3.6 \pm 0.7^{\star *}$ & $98 \pm 2.1^{*}$ & $39.3 \pm 4.5$ & $249 \pm 18.7^{*}$ \\
\hline Middle dose & $72.3 \pm 2.0^{* *}$ & $32.3 \pm 1.2^{* *}$ & $34.3 \pm 4.0$ & $3.1 \pm 1.4^{* *}$ & $96 \pm 2.0^{* *}$ & $44.3 \pm 1.5^{*}$ & $322.7 \pm 5.5^{\star}$ \\
\hline High dose & $61 \pm 1.0^{*}$ & $32 \pm 2.6^{* *}$ & $23 \pm 1.0^{*}$ & $2.1 \pm 0.6^{*}$ & $92.6 \pm 3.3^{* *}$ & $45.7 \pm 2.1^{*}$ & $326.7 \pm 2.9^{*}$ \\
\hline Control & $71.3 \pm 0.6$ & $37 \pm 2.0$ & $35.7 \pm 1.2$ & $5.7 \pm 0.1$ & $94.7 \pm 1.5$ & $34.3 \pm 2.3$ & $335 \pm 1.0$ \\
\hline
\end{tabular}

Values presented as mean \pm SEM, Significance relative to control: ${ }^{* *} p<0.01,{ }^{*} p<0.05$.

medicinal plants are concluded to be safe without understanding the possible health effects and thus commonly used in self-medication (Vaghasiya et al., 2011). Plants have produced these chemicals to protect themselves but research has shown that these chemicals in plant can also protect human against diseases (Falodun et al., 2006). These phytochemicals are also known to perform other functions. Some work as antioxidants, some exhibit hormonal actions, some stimulate enzymes, some interfere with DNA replication, and others have anti-bacterial effect while some possess other physical effect. Some of these plants chemicals though not distinguishable from the other metabolites which have therapeutic effect and defend the plants are toxic to humans. This explains why a large number of plants that produces them cannot be eventually useful in the formulation of drugs even though their parts may be biologically active.

The ethanol extracts of the stem bark of Blighia sapida was analyzed for the presence of phytochemical compounds which could be responsible for their medicinal use in traditional medicine (Tona 2008; Sofowora,
1999 and Olusegun, 2013). These chemicals could also include toxic component if there are any. Result obtained showed that the stem bark of $B$. sapida contained Saponin, Alkaloids, terpenes, cardiac glycosides Tannin and Balsam (Table 1). This result agrees with that of Olusegun (2013) and Ubulom et al. (2013). These phytochemical compounds have pharmacological effects and have been the basis of chemical synthesis of drugs used in modern medicine. They are also responsible for their use in traditional medicine (Sofowora, 2008).

The acute toxicity evaluation revealed that the lethal dose $\left(L D_{50}\right)$ of the ethanol stem bark extract of Blighia sapida was $500 \mathrm{mg} / \mathrm{kg}$ (Table 2). According to Homburger (1989), this extract can be said to be slightly toxic (500 to $5000 \mathrm{mg} / \mathrm{kg}$ ). The behavioral changes observed in the mice on administration were dullness, rubbing of nose and mouth on the floor of the cage along with restlessness.

The ethanol extract of the stem bark of $B$. sapida, both at sub-acute and chronic administrations (Tables $3 a$ and 4a) caused a significant reduction in the PCV which is evident in the reduction in RBC and HB. This suggests 
that the plant could precipitate some level of anaemia if the animals are exposed to it for a long period of time (Fahey, 2005). Meanwhile, reductions in the numbers of RBC (anaemia) may be associated with bone marrow suppression, as observed in cattle grazing on small quantities of bracken fern over several months (Knight and Walter, 2001).

The white blood cell (WBC) count for both the subacute and chronic toxicity testing (Table $3 b$ and $4 b$ ) were also decreased significantly. This decrease suggests that the extracts did not exhibit toxic effect even at high doses to trigger the release of the white blood cells. The lymphocyte, the main effector cells of the immune system (Mc Knight et al., 1999; Tédong et al., 2007) was also observed to decrease appreciably indicating that the extracts did not exert challenge on the immune system of the treated animals. The extract was also observed to have caused a significant decrease in the Platelets count. The reduction in platelet count suggests that blood clotting is impacted (American Association for Clinical Chemistry, 2014). Platelets also known as thrombocytes help to mediate blood clotting, which is a meshwork of fibrin fibres. The fibres also adhere to damaged blood vessels; therefore, the blood clot becomes adherent to any vascular opening and thus prevents further blood clot (Wu and Thyagarajan, 1996; Andrews et al., 1997; Cox and Cox, 2000). The extract could thus precipitate thrombocytopaenia which is the presence of low level platelets in the circulatory system as well as slow clotting of blood. This observation of decreased platelet level in the circulatory system by the extract also means that it may have anticoagulant property.

The ethanol extract of the stem bark of Blighia sapida caused a significant decrease in the AST level in the blood at both sub-acute and chronic toxicity test (Table $3 \mathrm{c}$ and $4 \mathrm{c}$ ). ALT and AST are produced in the liver and are good markers of damage to liver cells but not necessarily the severity of the damage (Rej, 1989). They are normally present at low levels in the blood so if the liver cells are damaged, it would be expected that some of the enzymes leak into the blood and increase in levels. The decrease in level of AST observed in this study may reflect no damage of liver cells. However, an increase in ALT level was observed. ALT is known to increase in liver disease and it has been used as a tool for measuring hepatic necrosis (Bush, 1991). The Increase in ALP may be considered as a sensitive indicator of cholestasis in early stages or mild circumstances preceding other indicators such as hyperbilirubinemia (Bush, 1991). The extract showed a decrease in urea level at both subacute and chronic toxicity test; low blood urea levels are not common and are not usually a cause for concern. This result may be seen when the system is overhydrated (too much fluid volume) or in cold weather when the body does not excrete much fluid from the system (Vasodilation) (Arise et al., 2012). The ethanol extract of the stem bark of Blighia sapida at sub-acute and chronic toxicity test result showed a decrease in the Albumin level. Albumin, apart from being a useful indicator of the integrity of glomerular membrane, is also important in determining the severity of disease (Adedapo et al., 2005). Decrease in albumin level may be due primarily to reduction in synthesis by the liver and secondary to reduced protein intake which further confirms a possible hepatic damage (Luskova et al., 2002; Jyotsna et al., 2003).

\section{Conclusion}

Findings from this study confirm that ethanol extract of the stem bark of Blighia sapida showed a slight toxicity to the Swiss albino mice. It also showed ability to precipitate some level of anaemia. Results obtained also confirmed that the extract had anticoagulant properties as well as the ability to cause hepatic damage.

\section{CONFLICT OF INTEREST}

The authors declare that they have no conflict of interest.

\section{REFERENCES}

Adedapo, A.A, Adegbayibi A.Y, Emikpe, B.O. (2005). Some clinico-pathological changes associated with the aqueous extract of the leaves of Phyllanthusamarus in Rats. Journ. Pharmacol and Toxicology, 19, 971-976.

American Association for Clinical Chemistry, (2014) edition. Safe laboratory procedure, 19-36.

Andrews, R. K, Lopez, J. A, Berndt, M. C. (1997). Molecular Mechanisms of Platelet Adhesion and Activation.Int. J. Biochem. Cell Biol., 29, 91.

Arise, R. O., Akintola, A. A., Olarinoye, I. B., \& Balogun, E. A. (2012). Effects of Aqueous Extract of Nauclea latifolia Stem on Lipid Profile and Some Enzymes of Rat Liver and kidney. Inter. J. Pharmacol., 8, 389-395.

Ashurust, P. R. (2001). Toxic Substances of Ackee. Rev. J. sci. Res., 2, 4-16.

Blanke, O. A., Bennink, M. R., \& Jackson, J. C. (2006). Ackee (Blighia sapida) Hypoglycin A Toxicity: Dose Response Assessment in Laboratory Rats, Food and Chemical Toxicology. Journ. Sci. Res., 44(2), 207-213.

Bush, B. M. (1991). Interpretation of Laboratory results for small animal Clinicians. Blackwell Scientific Publications: Oxford. Pp. 25-34.

Cox, D. L., \& Cox, M. M. (2000). Lehninger Principles of Biochemistry. Worth Publishers, New York. 877.

Ekue, M. R. M., Sinsin, B., Eyog-Matig, O., \& Finkeldey, R. (2010). Uses, Traditional Management, Perception of Variation and Preferences in Ackee (Blighia sapida K.D. Koenig) fruit traits in Benin: Implications for Domestication and Conservation. Journ. Ethnobiol, Ethnomed, 6(1), 12.

Fahey, J. W. (2005). A Review of the Medical Evidence for Its Nutritional, Therapeutic, and Prophylactic Properties.Part 1. Tree Life Journal, 1, 5-15.

Falodun, A., Okunrobo, L. O., Uzoamaka, N. (2006). Phytochemical Screening and Antilnflammatory Evaluation of 
methanolic and aqueous Extracts of Euphorbia heterophyllaLinn (Euphorbiaceae). Afr. J. Biotech., 5(6), 529531.

Harborne, J. B. (1973). Phytochemical Methods: A Guide to Modern Techniques of plant Analysis. Chapman and Hall Limited: London.

Homburger, F. (1989). In-vivo Testing in the Study of Toxicity and Safety Evaluation Guide to General Toxicology, Marquis J. K (ed.) 2nd edn, Karger, New York. Pp. 245-249.

Jyotsna, A. P., Arun, J. P., \& Sanjay, P. (2003). Biochemical effects of Various Pesticides on Sprayers of Grape garden. Indian Journ. Biochem., 18(21), 16-22.

Knight, A. P., \& Walter, R. G. (2001). Plants Affecting Blood: Bracken Fern Poisoning. In A.P. Knight \& R. G. Walter (Eds.), A Guide to Plant Poisoning of Animals in North America. Burbank, CA, USA: Teton New Media, Pp.195-197.

Kokwaro, J. O. (2000). Medicinal plants of West Africa. Africa Literature Bureau, Nairobi.

Kubmarawa, D., Ajoku, G. A., Enwerem, N. M., Okorie, D. A. (2007). Preliminary Phytochemical and Antimicrobial Screening of 50 Medicinal Plants from Nigeria. Afr. Journ. Biotech., 6(14), 1690-1696.

Lorke, D. A. (2003). New Approach to Practical Acute Toxicity Testing.Arch. Toxicol., 54: 275-286.

Luskova, V., Svoboda, M., \& Kolarova, J. (2002). The Effect of Diazinon on Blood Plasma Biochemistry in Carp (Cyprinuscarpio L). Acta Vet. Brno., 71, 117-123.

Mc Knight, D. C., Mills, R. G., Bray, J. J., \& Crag, J. J. (1999). Human Physiology. 4th Edn., Churchill, Livingstone, 290-294.

Okoli, A. S., \& Iroegbu, C.U. (2004). Evaluation and Extracts of Anthocleistadjalonensis, Nauclea latifolia and Uvariaafzalii for Activity against Bacterial Isolates from Cases of NonGonococcal Urethritis. J. Ethnopharmacol., 92(1), 135-144.

Olatunji, G. A., \& Atolani O. (2009). Comprehensive Scientific Demystification of Kigelia Africana. Afr. Journ.pure and appl. Chem., 3(9), 158-164.
Olusegun, O., John-Dewole, O., Oyedunni, P. (2013). Chemical, Phytochemical and Antimicrobial Screening of Extracts of B. sapidafor Agricultural and Medicinal Relevances. Nat. Sci.,11(10), 12-17.

Pincus, M. R., Tierno, P. M., Fenelus, M., Bowne, W. B., \& Bluth, M. H. (2011). Evaluation of liver function. In: McPherson, R. A, Pincus, M. R, eds. Henry's Clinical Diagnosis and Management by Laboratory Methods. 22nd ed. Philadelphia, PA: Elsevier Saunders, 1: 2011.

Rej, R. (1989). Aminotransferase in Disease. Clin. Lab. Med., 9(4), 667- 87.

Sofowora, A. (1999). African medicinal Plants.Medicinal Plant Research in Nigeria. Spectrum Books limited Ibadan. Pp. 455-462.

Sofowora, A. (2008). Medicinal plants and Traditional Medicine in Africa. 3rd ed, Spectrum Books limited Ibadan.

Tédong, L., Dzeufiet, P. D. D., Dimo, T., Asongalem, E. A., Sokeng, S. D., Flejou, J. F., Callard, P., \& Kamtchouing, P. (2007). Acute and Subchronic Toxicity of Anacardiumoccidentale Linn (Anacardiaceae) Leaves Hexane Extract in Mice. Afri. Journ. Trad. Complem. Alter. Med., 4(2), 140-147.

Tona, L., Kanbu, K., Nigimbi, N., Cimanga, K., \& Vietinck, A. J. (2008). Anti-Amoebic and Phytochemical Screening of some Congolese Medicinal Plant. Journ. Ethnopharmacol., 61(1), 57-65.

Trease, G. E., \& Evans, W. C. (2009).Pharmacognosy, New Edition, Bailliere Tindal, London, Pp. 225-255.

Vaghasiya, Y. K., Shukla, V. J., \& Chanda, S. V. (2011). Acute Oral Toxicity Study of Plucheaargutaboiss Extract in Mice. J. Pharmacol and Toxicol., 6, 113-123.

Wu, K. K., \& Thyagarajan, P. (1996). Role of Endothelium in Thrombosis and Haemostasis. Ann. Rev. Med., 47, 15. 